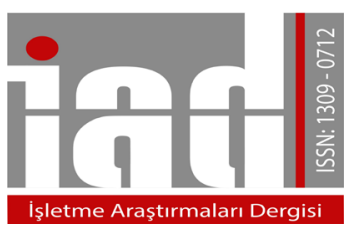

\author{
İşletme Araştırmaları Dergisi \\ Journal of Business Research-Turk \\ 10/4 (2018) 646-660
}

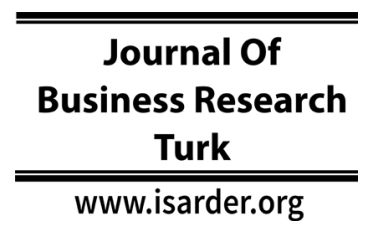

$\underline{\text { Research Article }}$

\title{
Match-fixing in Turkish Football Super League: Fenerbahçe Case
}

\author{
Banu Sultanoglu \\ Bilkent University \\ Faculty of Business Administration \\ Ankara, Turkey \\ orcid.org/0000-0003-0114-1553 \\ sbanu@bilkent.edu.tr
}

\author{
Guray Kucukkocaoglu \\ Baskent University \\ Faculty of Economics and Administrative \\ Sciences, Ankara, Turkey \\ orcid.org/0000-0001-6170-3269 \\ gurayk@,baskent.edu.tr
}

\author{
Özge Sezgin Alp \\ Baskent University \\ Faculty of Commercial Sciences \\ Accounting and Financial Management Department \\ Ankara, Turkey \\ orcid.org/0000-0003-3219-0948 \\ osezgin@,baskent.edu.tr
}

\begin{abstract}
Turkish football was hit hard by a sudden match-fixing scandal of Fenerbahçe during the 2010-2011 season with a 19.3\% slump on a day in the Istanbul Stock Exchange (currently known as Borsa Istanbul). This paper aims to asses the impact of news about the event of match-fixing that is claimed to have taken place in Fenerbahçe on its stock return volatility. To do this, all publicly available match-fixing announcements are collected and classified into five different news types to capture their individual effects on the volatility of Fenerbahçe's stock return by using GARCH model. Our results show that any positive or negative announcement released from Turkish court, Turkish Football Federation, the UEFA and/or the Court of Arbitration for Sport about Fenerbahçe and also any news about club executives allegedly involved in the event of match-fixing and the match results have significant positive effects on the Fenerbahçe's stock return volatility.
\end{abstract}

Keywords: Football, match-fixing, Fenerbahçe, Turkish Football Super League, stock price

Received 16 September 2018; Received in revised from 2 December 2018; Accepted 5 December 2018

\section{Suggested Citation:}

Sultanoğlu, B., Küçükkocaoğlu, G., Sezgin Alp, Ö. (2018). Match-fixing in Turkish Football Super League: Fenerbahçe Case, Journal of Business Research-Turk, 10 (4), 646-660. 


\section{Introduction}

Football has always been the most popular and lucrative team sport in Europe (Barak, 2014). In the twenty-first century, football is not just a game of eleven players anymore; it is an industry that generates a remarkable amount of money, mainly through sponsorship, merchandising and ticket revenues. According to Deloitte's Annual Review of Football Finance-Highlights report for 2016, the size of European football market is beyond $€ 20$ billion. Hence, considering the rapid growth in economic wealth of this industry, and the hurdle of under-capitalised financing, many football clubs started to float on the stock market in the 1980s (Dobson and Goddard, 2001). There are two worthy reasons to become public: first, it is an efficient source to cover the rising costs of expansion, and second, it increases the visibility and reputation of a team and fosters fan loyalty through public ownership (Glenn M.W., 2010). In 1983, the first Initial Public Offerings (IPO) of a football club launched with Tottenham Hotspurs on the London Stock Exchange (LSE) as an official list, and between 1995-2001 twentytwo football companies have floated on the same stock exchange. Currently, fourteen of them have been delisted due to the sharp decline in share prices and difficulty in profit generation (Wilson, Plumley and Ramchandani, 2013).

Publicly traded football clubs have their unique risks and challenges which make them distinctive in contrast to other companies listed on the stock exchange (Hamil and Morrow, 2011). First, the stock price can take a hit or drive the price up due to a failure or success in the field and therefore becomes a vital sign of stock price sensitivity, even more so than its financial position (Cheffins, 1998; Renneboog and Vanbrabant, 2000; Duque and Ferreira, 2005; Gils, 2016), second club fans or football supporters act as the crucial supportive investors for listed football clubs, often hold their clubs' shares for sentimental reasons (Cheffins, 1998; Morrow, 1999; Renneboog and Vanbrabant, 2000; Duque and Ferreira, 2005; Harty, 2014; Gils, 2016) in terms of the sense of identity and belonging to their clubs and third the presence of a dominant chairman or high management intervention (Dobson and Goddard, 2001; Morrow, 1999). Thus, sporting outcomes would never be ignored for the analysis of a stock performance from the investors' standpoint. A substantial amount of literature has been built up that analyzes publicly traded football companies' stock price reactions to news on match results. However, no one ever has expected that sudden bad news, rather than a loss in a match, that the stock price of a football club would take a big dive over a single night resulting, in a drastic decline to its previous 18 months' level. Such an event was observed in Turkey after the reported allegations about match-fixing in the European-renowned football club, Fenerbahçe.

This study investigates the impact of news about the match-fixing event on Fenerbahçe's stock return volatility during the 2010-2011 season. To accomplish this, we used the publicly available match-fixing news data and classified them into five different types to assess their individual effects.

The remainder of this paper is organized as follows: The next section provides a brief summary of match-fixing phenomena in Europe. Following this summary, the next section provides chronological information about the match-fixing events in Turkish football. Next is the relevant literature establishing the justifications on our research. Following the literature review, the next two sections present the proposed methodology 
and discuss the study findings. The paper concludes with a discussion on the key findings.

\subsection{Match-fixing Phenomena in the European Football}

Match-fixing simply means the act of changing the unpredictable result of a football match into a predictable one (Kalb, 2011). Money and greed are the main drivers of match-fixing. It happens in two ways: betting or non-betting-related activities. In a betting-related activity, the main goal of the involved parties is to make money through gambling, with a guaranteed result (direct financial motivation), whereas a nonbetting activity is the act of altering the result of any match to create sporting advantage; i.e. winning a match or being eligible to a higher level of competition (direct sports motivation) and financial advantage (indirect financial motivation) (Kalb, 2011). In this research, the emphasis is put on the latter; the non-betting one.

The outcome of conducting successful match-fixing without the participants being arrested is expected to be enormous for the sake of the club in terms of gaining both money and position. However, the other way around, there could be major ramifications, such as penalties from governing bodies, criminal sanctions and reputational damage (Carpenter, 2012). Among these, reputational damage is deemed the most significant, destroying, the name of the club.

Match-fixing is not a new phenomenon in the European football. The first matchfixing case dates back to $1915^{1}$. Manchester United fixed a match with Liverpool and was prevented from relegation. A similar case happened in 1979 in the last match of the Italian Serie championship between Juventus and Avellino, in Avellino's favour. The match-fixing in the 1982 World Cup game between West Germany and Austria engraved this event into everyone's memory.

Over the past ten years, due to remarkable growth of the football industry, matchfixing has become a big threat to the integrity of sport, especially for the European football. According to the results of the largest football match-fixing investigations carried out by Europol and police teams from 13 European countries, a total of 425 people were accused of fixing 380 professional matches. These organized crime activities generated more than $€ 8$ million in betting profits and over $€ 2$ million in corrupt payments to those involved in the matches (Europol 2013). Some selected highprofile corruption examples are listed, from the 2005-2006 and 2011 Italian football scandals in Serie A and B Leagues; the Apito Dourado operation in Portuguese Football League in the years of 2004-2008; and Europe's biggest in Germany, the 2009 Bochumcase where, police arrested 17 people for rigging nearly 200 matches in nine countries. A final example comes from Finland, where the penultimate match-fixing scandal ended with the indefinite suspension of a football team from the Finnish League for receiving corrupt payments between the years of 2008-2011, as a result of a worldwide known match-fixer.

\subsection{Match-fixing in Turkey}

According to a survey conducted in 2013 by SMG Insight, Sports Turkey: Popularity of Sports in Turkey, football is the most followed sport in Turkey. In 2016, Turkish football clubs' total brand value was worth around \$211 million. The Turkish

\footnotetext{
${ }^{1}$ Match-fixing in sport. A mapping of criminal law provisions in EU 27, KEA European Affairs, March 2012 www.keanet.eu/docs/study-sports-fraud-final-version_en.pdf
} 
football league system is comprised of 5 professional leagues, where the Super League is the top division and includes 18 clubs. Among them, Fenerbahçe, Galatasaray, Beşiktaş and Trabzonspor are considered to be the most successful and are also known as the Big 4.

Fenerbahçe Sports Club is the most valuable one holding the 45th position in the Brand Finance Football 50 with current market value of $\$ 95$ million. The club's company, Fenerbahçe Futbol A.Ş. (Fenerbahçe) manages the sporting, educational, legal and economic activities of the football team, and its shares have been traded with the "FENER" ticker in the Borsa Istanbul (BIST) since 2004.

Aziz Y1ldırım has served as the chairman of Fenerbahçe since 1998, becoming an idol for Fenerbahçe fans through his initiatives of making Fenerbahçe a globally known club. Over the years, Yıldırım has developed a strong bond with his club fans who never think of Fenerbahçe without him. With his aggressive passion, Yıldırım became a very strong force for Fenerbahçe, even starting to rule the whole Turkish football through the Turkish Clubs Union Association. His strong personality, along with his passion, drew many reactions from other clubs. But yet, in July 2011, he was swept up and allegedly accused of match-fixing events for his team, perhaps the largest incidence of football corruption in Turkey. Referring to Boniface et al.'s (2012) classification ${ }^{2}$, it is the institutional form of fixing with the conventional way of buying the match with the organized efforts of the club executives.

The chain of events began on July 3, 2011, with a police investigation and 61 officials being arrested for match-fixing, the use of incentive premium, bribery, and leading a criminal organization probe into the with officials of Peker family, known to have links with the Mafia. Several important figures, mainly from Fenerbahçe, were sentenced to imprisonment for offenses related to match-fixing activities in the 19 Super League football matches needed to win the 2010-2011 Turkish Championship. These individuals included Yıldırım, the chairman; Mehmet Şekip Mosturoğlu, the vice chairman; İlhan Ekşioğlu and Alaaddin Yıldırım, board members; Cemil Turhan, the sports director; and Tamer Yelkovan, the finance director. Furthermore, dozens of individuals whose names are associated with Trabzonspor, the league's runner-up, and Beşiktaş, the cup winner, were questioned in the course of the investigation.

In April 2011, more shocking news occurred on the first trading day of when Fenerbahçe's stock prices fell drastically by $19.3 \%$. Then four days later, after Fenerbahçe's declaration of this issue to Public Disclosure Platform, the market value continued to decline to where it had been 18 months ago.

In August 2011, the Turkish Football Federation (TFF) announced its official decision to withdraw Fenerbahçe from the 2011-2012 European Champions League at the request of the UEFA. Fenerbahçe applied to Court of Arbitration for Sport (CAS) to appeal the Champions League's decision. However, in September 2011, this application was refused.

\footnotetext{
${ }^{2}$ Boniface, Lacarriere, Verschuuren, Tuaillon, Forrest, Icard, Meyer, and Wang (2012) classified match-fixing into three categories: 1) fraud in sport at the grassroots level, 2) institutional fraud in sport and 3) exogenous sporting fraud. In the first one, the coach directs the manipulation process, whereas in the second one the act is institutionalised in the club and mainly led by the chairman. The third form is betting-related match manipulation
} 
During 2012, TFF's Ethics Committee, the Professional Football Discipline Committee and the court all agreed: Fenerbahçe executives were involved in matchfixing activities that resulted in winning the Super League championship in the 20102011 season.

In June 2013, UEFA banned Fenerbahçe from European competitions for a period of two seasons. At the same time, the convicted people won a retrial scheduled for January 2015. Finally, on October 6, 2015, the chairman of Fenerbahçe and 35 other defendants were acquitted of match-fixing charges in the retrial stemming where Fenerbahçe fans celebrated the decision outside the courthouse.

\section{Literature}

In this area of research, English football teams traded on the London Stock Exchange (LSE) have become the most widely analyzed sample due to the popularity of the league, availability of a large amount of data, and a diverse range of variables. Early studies used raw match scores (win, loss and draw) to examine the linkage between sport and subsequent stock performance of football teams. For instance, Morrow (1999) carried out the first pertinent study based on two British football clubs and observed share price increases and decreases after wins and losses, respectively. Renneboog and Vanbrabant (2000) did a subsequent study using the weekly results of 17 British football teams listed on the LSE and Alternative Investment Market (AIM) between 1995 and 1998. Their findings reveal that victories are rewarded by share price increases for the teams listed on the LSE, whereas defeats or draws result in large price decreases for AIM-listed teams. An extensive study undertaken by Ashton, Gerrard, and Hudson (2003), which included all English national football teams, examined the impact of international football results on the FTSE 100 Index. They employed an event study analysis and found that good performances (wins) and bad performances (losses) were followed by good and bad market returns, respectively. Following the influential paper of Ashton, Gerrard, and Hudson (2003), some subsequent studies continued to assess the same research question in terms of British (Dobson and Goddard, 2001; Palomino, Renneboog, and Zhang, 2009; Dohmen, Falk, Huffman, and Sunde, 2006), German (Stadtmann, 2006), Portuguese (Duque and Ferreira, 2005), Turkish (Aygoren, Uyar, and Saritaş, 2008; Berument, Ceylan, and Eker, 2009, 2012; Özdurak and Ulusoy, 2013; Saraç and Zeren, 2013; Güngör, 2014) and other cross-cultural data (Edmans, Garcia, and Norli, 2007; Benkraiem, Louchichi, and Marques, 2009; Kaplanski and Levy, 2010; Scholtens and Peenstral, 2010; Floros, 2014). These studies found a strong association between stock performance of individual teams and their wins and losses. Most of the aforementioned studies observe asymmetric stock market responses - that is, stronger stock market reactions after losses than wins. However, Palomino et al. (2009) report the opposite for British data. Additionally, Edmans et al. (2007) examined the data from 39 stock markets and found that losses significantly influenced stock returns, but they did not observe any corresponding effect for wins. On the other hand, Kaplanski and Levy (2010) worked with FIFA World Cup results and concluded that the association between stock performance of teams and their wins and losses is observed to be robust. Benkraiem et al. (2009) undertook an event study on 745 matches played by European listed football clubs between 2006 and 2007 demonstrating that the stock market reaction is significantly linked to the match venue and sporting result. Scholtens and Peenstral (2010) employed a multi-country study and included 1,274 matches of eight international football teams in national and European 
competitions during 2000-2004. They found significant and positive abnormal returns for victories and negative but larger abnormal returns for defeats in European competitions than for those in national competitions.

Hence, all of these studies point to a common result that stock markets significantly react to news about match results. The research on the reaction of stockexchange on match-fixing events is limited. This paper contributes to the scarce existing literature by focusing on the stock price reaction of news about match-fixing in Turkey. Nowy and Breuer (2016) discussed match-fixing in a different context in their study. Based on 3,004 European football clubs in five countries, they discussed the issue from a sociological and economic perspective and analyzed within the organizational capacity framework. Gökten and Karatepe (2015) analyzed the effects of football-clubrelated events, caused by match-fixing activities, on the stock prices of the Big 4 using event study methodology, and they found statistically significant positive effects on their stock performance around the publication date. Further, Tufan and Hamarat (2014) compared the Big 4 stock returns and trading volumes during accusation and nonaccusation periods by using nonparametric tests, and they observed a significant difference between the returns of Trabzonspor and Fenerbahçe before and after matchfixing accusation periods, but not for Galatasaray and Beşiktaş. Demir and Karademir (2013) examined the participants, vehicles and processes of match-fixing by applying the case of the aforementioned scandal and suggested some policy implementations regarding the context and dimensions of match-fixing in Turkey.

\section{Data and Methodology}

Our main dataset covers 1,189 observations collected over the period of January 14, 2011 to October 6, 2015 and comprised of daily closing stock prices of Fenerbahçe quoted in BIST 100 and all publicly available match-fixing announcements obtained from the sports website of the Turkish journal "Milliyet". The dataset was further crosschecked using the Bloomberg "news" page related to Milliyet and the Mackolik Internet Service Provider for match results. The news about match-fixing event were parsed out into five categories: Turkish court decisions, TFF announcements, announcements about executives and players alleged to be involved in the case, UEFA, and CAS announcements. In addition to these news variables, match results were also considered that influenced the volatility and BIST $100 \mathrm{Index}^{3}$ return as a market proxy. Daily stock price returns ${ }^{4}$ for Fenerbahçe $\left(\right.$ FENER $^{5}$ ) and BIST 100 were computed and are shown in Figure 1:

\footnotetext{
${ }^{3}$ In Turkey, BIST 100 is used as a market index.

${ }^{4}$ Return $_{\mathrm{t}}=\left(\mathrm{P}_{\mathrm{t}}-\mathrm{P}_{\mathrm{t}-1}\right) / \mathrm{P}_{\mathrm{t}-1}$

${ }^{5}$ Ticker symbol for Fenerbahçe shares in BIST 100 Index
} 


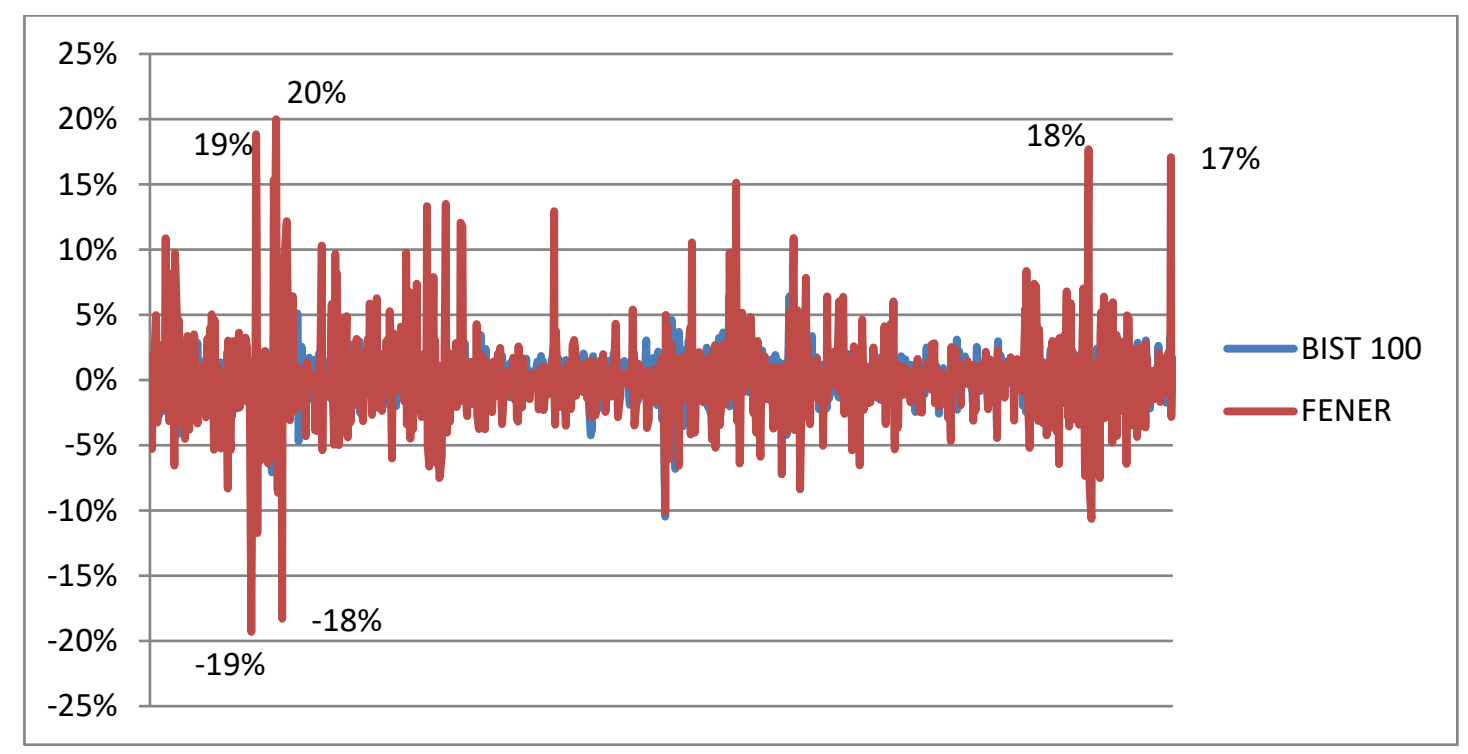

Figure 1: FENER and BIST 100 Index Returns

Figure 1 highlights the development of the stock price of Fenerbahçe on and around the time of the allegations of match-fixing news. Daily returns are plotted for FENER and BIST 100 Index during the observation period. Two sharp downward and four upward movements are obvious and required explanation. Initially, Fenerbahçe shares suffered a significant loss of $19 \%$ on July 4, 2011, following the first matchfixing investigation news that emerged in the media. Then, on July 12, 2011, an announcement from TFF declared that the Super League would continue as it was, due to the inexistence of any supportive evidence on match-fixing, and Fenerbahçe shares advanced a sharp increase of $19 \%$. Another jump on Fenerbahçe shares (a $20 \%$ increase in a single trading day) was observed on August 15, 2011, due to the deferral of the TFF decision of "no evidence," easing concerns of Fenerbahçe investors. Unfortunately, only ten days after TFF's statement, a controversial decision made by the same institution to withdraw Fenerbahçe from the 2011-2012 European Champions League. Fenerbahçe's stock price once again plummetted by more than $18 \%$, and prolonged discussions began. Another noteworthy event happened in May 2015, when Galatasaray won the Super League title. As expected, Galatasaray shares appreciated a lot, but Fenerbahçe's shares also reacted positively to this good news and rose by $18 \%$, as the two teams (and their shares) have a long-standing rivalry with each other. Finally, on October 6, 2015, when the chairman of Fenerbahçe and 35 other defendants were acquitted of matchfixing charges by a Turkish court, investors celebrated this decision with a $17 \%$ sharp increase in Fenerbahçe stock prices.

To investigate the impact of publicly announced events on stock returns, the general tendency is to use Sharpe's market model with linear regression. However, Mandelbrot (1963) and Fama (1965) found that stock returns exhibit volatility clustering and assumptions of classical linear regression are violated. In 1982, Engle developed a new class of model for the time varying variance called Autoregressive Conditional Heteroscedasticity (ARCH) model and in 1986 Bollerslev generalized the ARCH model and developed Generalized ARCH (GARCH) model. As many industrial and sytematic factors are affecting the stock market volatility, volatility becomes the measure of risk showing the deviation from expected return. It gives intution about how often and in what ranges the stock market changes. Therefore, there is a strong 
relationship between volatility and stock return performance. For this purpose GARCH model is used to test the significance of news affecting Fenerbahçe's daily return volatility.

In the GARCH type models there are two equations: 1) is the conditional mean equation describing the time varying movements of dependent variable and 2) is the conditional variance equation including the unobservable residual from conditional mean equation and lag values of conditional variance as an input to model conditional variance. Therefore, GARCH models can successfully capture the stylized facts of asset returns and volatility clustering. The conditional mean and volatility equations of the model used in this paper can be denoted as follows:

$$
\begin{aligned}
& \text { FENER }_{t}=\alpha_{0}+\alpha_{1} \text { BISTR }_{t}+\varepsilon_{t} \quad \varepsilon_{t}: \operatorname{Normal}\left(0, \sigma^{2}{ }_{t}\right) \\
& \begin{aligned}
\sigma_{t}^{2}= & \beta_{0}+\beta_{1} \varepsilon_{t-1}{ }^{2}+\beta_{2} \sigma_{t-1}{ }^{2}+\beta_{3} D_{\text {TRCASEt }}+\beta_{4} D_{\text {TRTFFt }}+\beta_{5} D_{\text {TREXEC } t}+\beta_{6} D_{\text {TRPLAYER } t} \\
& +\beta_{7} D_{\text {UEFACASt }}+\beta_{8} D_{\text {WIN }}+\beta_{9} D_{\text {LOSSt }}+\beta_{9} D_{\text {DRAW }}
\end{aligned}
\end{aligned}
$$

where FENER is Fenerbahçe's daily return; BISTR is the market return; and DTRCASE, DtrtfF, DtReXeC, DTRPLAYER, DUEFACAS are assigned as dummy variables to account for the five categories of news about match-fixing activities. Further, DWIN, $D_{L O S S}, D_{D R A W}$ are the dummies to test for match results as win, loss and draw, respectively. The mean equation is formed through the use of the Capital Asset Pricing Model (CAPM). To be more specific, the list of variables in our model is also presented in Table 1:

\section{Table 1: List of Variables in the Model}

\begin{tabular}{|c|l|}
\hline Variable Name & Description \\
\hline BISTR & BIST 100 Index Return \\
TRCASE & $\begin{array}{l}\text { Announcements made by Turkish court related to the ongoing } \\
\text { case. }\end{array}$ \\
TRTFF & $\begin{array}{l}\text { Announcements made by TFF and other related organizations. } \\
\text { Announcements including executives alleged to be involved in the } \\
\text { case. }\end{array}$ \\
TREXEC & $\begin{array}{l}\text { Announcements including players alleged to be involved in the } \\
\text { case. }\end{array}$ \\
URPLAYER & Announcements made by UEFA and/or CAS. \\
WIN & The match is won by Fenerbahçe. \\
LOSS & The match is lost by Fenerbahçe. \\
DRAW & The match outcome is no win, no loss. \\
\hline
\end{tabular}

The above listed variables were assigned by dummy explanatory variables. For example, the dummy variable takes the value of " 1 " if any type of announcement listed in Table 1 is made, and " 0 " otherwise. Also assigned was the value of " 1 " for the next business day for both the announcements made and match played outside the trading days of BIST 100. For the match results, three dummy variables were used (win, loss, draw) by assigning " 1 " when the club wins and "0" otherwise.

\section{Empirical Results}

Table 2 reports the descriptive statistics for the continuous variables. As seen from the table, the variables have positive or negative skewness values. The kurtosis statistics also show that data is not normally distributed. Jarque-Bera test results reject the null hypothesis of normality. 
Table 2: Descriptive Statistics

\begin{tabular}{|l|c|c|c|c|c|c|}
\hline Variables & Mean & Std. Dev. & Skewness & Kurtosis & Jarque-Bera & Probability \\
\hline BISTR & 0.000258 & 0.014932 & -0.496828 & 6.659989 & 713.7501 & $0.0000^{* * *}$ \\
\hline TRTFF & 0.023510 & 0.151579 & 6.289657 & 40.55979 & $77,860.48$ & $0.0000^{* * *}$ \\
\hline TRCASE & 0.064652 & 0.246013 & 3.540714 & 13.53665 & $7,997.945$ & $0.0000^{* * *}$ \\
\hline TRPLAYER & 0.000840 & 0.028976 & 34.46739 & 1189.001 & $70,038,244$ & $0.0000^{* * *}$ \\
\hline TREXEC & 0.057935 & 0.233718 & 3.784490 & 15.32237 & $10,378.09$ & $0.0000^{* * *}$ \\
\hline UEFACAS & 0.040302 & 0.196750 & 4.674879 & 22.85449 & $23,900.34$ & $0.0000^{* * *}$ \\
\hline WIN & 0.111671 & 0.315093 & 2.465886 & 7.080596 & $2,033.317$ & $0.0000^{* * *}$ \\
\hline LOSS & 0.031066 & 0.173570 & 5.405668 & 30.22125 & $42,572.37$ & $0.0000^{* * *}$ \\
\hline DRAW & 0.038623 & 0.192776 & 4.788682 & 23.93148 & $26,293.94$ & $0.0000^{* * *}$ \\
\hline
\end{tabular}

*** indicates statistically significant at the level of $1 \%$.

As a part of our study, returns are clustered into two categories as: 1) a set of returns on the event days, defined as any match-fixing announcements and/or match result days, and 2) a set of returns on the non-event days, when no match-fixing and/or match results were announced. The difference of means were tested for the difference of means between event days and non-event days and reported in Table 3:

Table 3: Mean Differences in Test Results

\begin{tabular}{|c|c|c|c|c|}
\hline Variables & $\begin{array}{c}\text { Event }(\mathrm{N}=\mathbf{8 4 2}) \\
\text { NonEvent } \\
(\mathrm{N}=\mathbf{3 4 7})\end{array}$ & Mean & F-value & p-value \\
\hline \multirow{2}{*}{ FENER } & $\mathrm{E}$ & 0.0013 & \multirow{2}{*}{1.96} & \multirow{2}{*}{$0.0978 *$} \\
\hline & $\mathrm{N}$ & -0.0001 & & \\
\hline \multirow{2}{*}{ BISTR } & $\mathrm{E}$ & -0.0001 & \multirow{2}{*}{0.55} & \multirow{2}{*}{0.7024} \\
\hline & $\mathrm{N}$ & 0.0000 & & \\
\hline \multirow{2}{*}{ TRTFF } & $\mathrm{E}$ & 0.0000 & \multirow{2}{*}{53.44} & \multirow{2}{*}{$0.0000^{* * *}$} \\
\hline & $\mathrm{N}$ & 0.0234 & & \\
\hline \multirow{2}{*}{ TRCASE } & $\mathrm{E}$ & 0.0000 & \multirow{2}{*}{417.39} & \multirow{2}{*}{$0.0000^{* * *}$} \\
\hline & $\mathrm{N}$ & 0.0645 & & \\
\hline \multirow{2}{*}{ TREXEC } & $\mathrm{E}$ & 0.0000 & \multirow{2}{*}{430.40} & \multirow{2}{*}{$0.0000^{* * *}$} \\
\hline & $\mathrm{N}$ & 0.0579 & & \\
\hline \multirow{2}{*}{ TRPLAYER } & $E$ & 0.0000 & \multirow{2}{*}{3.60} & \multirow{2}{*}{$0.0063 * *$} \\
\hline & $\mathrm{N}$ & 0.0008 & & \\
\hline \multirow{2}{*}{ UEFACAS } & $E$ & 0.0000 & \multirow{2}{*}{39.42} & \multirow{2}{*}{$0.0000^{* * *}$} \\
\hline & $\mathrm{N}$ & 0.0402 & & \\
\hline \multirow{2}{*}{ WIN } & $\mathrm{E}$ & 0.0000 & \multirow{2}{*}{166.50} & \multirow{2}{*}{$0.0000^{* * *}$} \\
\hline & $\mathrm{N}$ & 0.1115 & & \\
\hline \multirow{2}{*}{ LOSS } & $\mathrm{E}$ & 0.0000 & \multirow{2}{*}{26.17} & \multirow{2}{*}{$0.0000^{* * *}$} \\
\hline & $\mathrm{N}$ & 0.0310 & & \\
\hline \multirow{2}{*}{ DRAW } & $\mathrm{E}$ & 0.0000 & \multirow{2}{*}{37.44} & \multirow{2}{*}{$0.0000^{* * *}$} \\
\hline & $\mathrm{N}$ & 0.0385 & & \\
\hline
\end{tabular}

$* * *, * * *$ indicates statistically significant at the levels of $1 \%, 5 \%$ and $10 \%$. 
The results reveal that FENER is statistically significant at the $10 \%$ level, which is in line with the findings of Tufan and Hamarat, 2014. The variables in the model, except BISTR, are all significantly different between the event days and non-event days.

Table 4: GARCH Model Parameters for Fenerbahçe Stock Return

\begin{tabular}{|c|}
\hline FENER $=\mathrm{C}(1)+\mathrm{C}(2) * \mathrm{BISTMR}$ \\
\hline $\mathrm{GARCH}=\mathrm{C}(3)+\mathrm{C}(4) * \mathrm{RESID}(-1)^{\wedge} 2+\mathrm{C}(5) * \mathrm{GARCH}(-1)+\mathrm{C}(6) * \mathrm{TRCASE}+$ \\
\hline $\mathrm{C}(7) * \mathrm{TRTFF}+\mathrm{C}(8) * \mathrm{TREXEC}+\mathrm{C}(9) * \mathrm{TRPLAYER}+\mathrm{C}(10) * \mathrm{UEFACAS}+$ \\
\hline $\mathrm{C}(11) * \mathrm{WIN}+\mathrm{C}(12) * \mathrm{LOSS}+\mathrm{C}(13) * \mathrm{DRAW}$ \\
\hline
\end{tabular}

\begin{tabular}{|l|c|c|c|c|}
\hline \multicolumn{5}{|c|}{ Mean Equation } \\
\hline Variable & Coefficient & Std. Error & z-Statistic & Prob. \\
\hline C(1) & -0.000230 & 0.000623 & -0.369762 & 0.7116 \\
\hline C(2) & 0.558045 & 0.026181 & 2.131455 & $* * 0.0000$ \\
\hline \multicolumn{5}{|c|}{ Variance Equation } \\
\hline C & $8.62 \mathrm{E}-05$ & $1.09 \mathrm{E}-05$ & 7.937864 & $* * 0.0000$ \\
\hline RESID(-1)^2 & 0.430058 & 0.039053 & 1.101222 & $* * 0.0000$ \\
\hline GARCH(-1) & 0.287590 & 0.027163 & 1.058742 & $* * 0.0000$ \\
\hline TRCASE & 0.000171 & $9.33 \mathrm{E}-05$ & 1.836183 & $* * 0.0063$ \\
\hline TRTFF & 0.004330 & 0.000835 & 5.185495 & $* * 0.0000$ \\
\hline TREXEC & 0.001117 & $8.34 \mathrm{E}-05$ & 1.338953 & $* * 0.0000$ \\
\hline TRPLAYER & 0.003632 & 0.012905 & 0.281415 & 0.7784 \\
\hline UEFACAS & 0.000761 & 0.000135 & 5.632670 & $* * 0.0000$ \\
\hline WIN & 0.000521 & $6.10 \mathrm{E}-05$ & 8.539491 & $* * 0.0000$ \\
\hline LOSS & 0.000172 & $7.98 \mathrm{E}-05$ & 2.159623 & $* 0.0308$ \\
\hline DRAW & 0.000560 & $9.20 \mathrm{E}-05$ & 6.082598 & $* * 0.0000$ \\
\hline
\end{tabular}

$* *, *$ indicates statistically significant at the levels of $1 \%, 5 \%$

As seen from the Table 4 the constant term for the mean equation is insignificant while the coefficient of BISTR market return is positively significant which is a consistent result with CAPM. This result indicates that stock price is not free from the BIST 100 effect, which is also supported by the findings of Saraç and Zeren, 2013. In other words, this may be a result of strong macroeconomic effects incorporated in the BIST 100 variable that should be considered as a real existence of systemmatic risk.

Our results indicate that any positive or negative announcement related to the match-fixing event of Fenerbahçe caused a significant change in the stock market returns and volatility shocks. The estimated coefficients of TREXEC, TRCASE, TRTFF and UEFACAS are all positive and statistically significant, indicating that a potent belief exists in both the domestic and foreign judicial systems in Turkey. In other words, any positive (negative) announcements made by the Turkish court or TFF related to the ongoing case were directly taken into account by the Turkish investors, including a very forceful group of fans and led to a significant increase in stock return volatility of 
Fenerbahçe. Likewise, series of declarations that were made by UEFA significantly affected the stock's volatility including a final penalty decision that was given for Fenerbahçe to withdraw from the 2011-2012 European Champions League. Similarly, several announcements by CAS about the refusal of Fenerbahçe's application on this issue influenced the stock's volatility. Throughout the research, most of the news on TREXEC concentrated on Fenerbahçe's chairman, Aziz Y1ldırım, and allegations that he orchestrated a series of match-fixing activities. From the football club's supporters standpoint, who put their sole trust in Aziz Y1ldırım and their team without any doubt, this was more than unbelievable. From an investor's standpoint, reactions on the news about him were very harsh and negative, explaining the significant positive effect of TREXEC variable on stock's volatility. This finding may imply the strong and dominant chairman effect which may act as a deterrent to the supporters' thoughts about the club and its chairman.

The only insignificant variable is TRPLAYER representing announcements about football players who have no significant effect on stock retun volatility. Football player transfers have an effect on a club's on-field performance (Brommer, 2011) and football players are becoming known as the most expensive intangible assets for football clubs, it is expected that the news about transfers should have a significant effect on clubs' shares. However, during the match-fixing event period, the clubs' shares were not subject to this effect, Fenerbahçe Soccer club did not sign on any reputable or otherwise transfer any sensational football players.

The estimated coefficients of the WIN, DRAW and LOSS variables significantly increase the volatility of stock prices, and investors responded vigorously to the match results on Fenerbahçe's games which is parallel the findings of Berument et al. (2009).

\section{Conclusion}

This paper investigates the impact of match-fixing announcements on Fenerbahçe's stock return volatility, alleged to have taken place in Fenerbahçe's Turkish Football Super League matches during the 2010-2011 season. The study differs from previous studies searching for links between the sporting results and the football clubs' shares. It investigates the effect of classified match-fixing events on one of the Big 4, namely Fenerbahçe's shares and found that any positive or negative relevant announcements made by the Turkish court, TFF, UEFA and CAS directly affected the decisions of Turkish investors which in turn caused an increase in the volatility of Fenerbahçe's stock returns. Also, the fans showed an expected reaction when the announcements about executives, mainly about Aziz Y1ldırım were made. With his aggressive passion he has become the driving force for the team and developed a strong bond with his fans. As long as these type football clubs run by a one-man show, where the chairman sets up the team, transfers the players, solicits the public relations, manages the budgets, he eventually becomes a one-man band. At the end of the day, he is held responsible for every decision he has made in the club, as in the case of matchfixing. Therefore, we are inclined to conclude that, measures must be implemented to strengthen the football organisational structures in terms of reducing chairman dominance and relevant legislation must also be in place to prevent the instances of match-fixing.

This study also provides an opportunity for further research into what is the most effective economic outcome of banning Fenerbahçe from European competitions for a 
period of two seasons. After all, on October 6, 2015, the chairman of Fenerbahçe and 35 other defendants were acquitted of match-fixing charges in a retrial stemming from the 2011 corruption scandal. Further research could also focus on alternative ways to monetarize the impact of such a ban on Turkish football. Additional research could explore more deeply Turkish daily Star's columnist Hüseyin Gülerce's accusation that the Gülenist Terror Organization FETÖ, plotted the Fenerbahçe match-fixing case in 2011 ${ }^{6}$. Fenerbahçe President Aziz Yıldırım and several others were imprisoned for months before being acquitted, in what Y1ldirım describes as "a plot to take over Fenerbahçe". How that news affected volatility for the club after the acquittal could be investigated.

\section{References}

Ashton, J.K., Gerrard, B. and Hudson, R. (2003). "Economic impact of national sporting success: Evidence from the London stock exchange", Applied Economics Letters, Vol. 10, pp.783-785.

Aygoren, H., Uyar, S. and Saritaş, H. (2008). "Are investors affected by the results of football matches? An example from Borsa Istanbul", H. ̈. Iktisadi ve İdari Bilimler Fakültesi Dergisi, Vol. 26, No.1, pp. 121-137.

Barak, E. (2014). "Top 10 most popular sports in the world in 2016", available at: http://www.top10zen.com/most-popular-sports-1584.

Benkraiem, R., Louchichi, W. and Marques, P. (2009). "Market reaction to sporting results: the case of european listed football clubs", Management Decision, Vol. 47, No.1, pp. 100-109.

Berument, H., Ceylan, N.B. and Gozpinar, E. (2006). "Performance of soccer on the stock market: Evidence from Turkey", Social Science Journal, Vol. 43, pp. 695699.

Berument, H. and Ceylan, N.B. (2012). "Effects of soccer on stock markets: The returnvolatility relationship", Social Science Journal, Vol. 49, pp. 368-374.

Berument, H., Ceylan, N.B. and Eker, G.O. (2009). "Soccer, stock returns and fanaticism: Evidence from Turkey”, Social Science Journal, Vol.46, pp. 594-600.

Boniface P. et al. (2012). Sports betting and corruption-how to preserve the integrity of sport", available at: http://www.sportaccord.com/multimedia/docs/2012/02/2012-_ENG.pdf

Brand Finance (2016). "Football 50”, 6 June, p. 6.

Carpenter, K. (2012). "Match-fixing- the biggest threat to sport in the 21st century? executive contributor", available at: http://www.lawinsport.com/articles/anticorruption/item/match-fixing-the-biggest-threat-to-sport-in-the-21st-century-part$1 ?$

\footnotetext{
${ }^{6}$ Match-fixing case a Gülenist plot against Fenerbahçe, http://www.dailysabah.com/football/2016/08/02/match-fixing-case-agulenist-plot-against-fenerbahce, Received 02/08/2016.
} 
CAS (2013). CAS 2013/A/3256 Fenerbahçe Spor Kulübü v. UEFA Arbitral Award delivered by the Court of Arbitration for Sport, available at: http://www.tascas.org/fileadmin/user_upload/Award 3256_FINAL_internet.pdf.

Cheffins, B.R. (1998). "Playing the stock market: going public and professional team sports", Journal of Corperation Law, Vol. 24, pp. 642 - 679.

Daily Sabah (2016). "Match-fixing case a Gülenist plot against Fenerbahçe", 1 August, available at: http://www.dailysabah.com/football/2016/08/02/match-fixing-case-agulenist-plot-against-fenerbahce

Deloitte (2016). Annual Review of Football Finance-Highlights, available at: http://www2.deloitte.com/content/dam/Deloitte/global/Documents/AboutDeloitte/gx-deloitte-uk-arff-2016-highlights.pdf

Demir and Karademir (2013). "Catching sports cheaters: An example of successful police operations"in Haberfeld, M.R., Sheehan, Dale (Ed.), Match-Fixing in International Sports, Existing Processes, Law Enforcement, and Prevention Strategies, Springer, pp. 331-348.

Dohmen, T., Falk, A., Huffman, D. and Sunde, U. (2006). "Seemingly irrelevant events affect economic perceptions and expectations: The FIFA World Cup 2006 as a natural experiment”. IZA Discussion Papers No: 2275.

Dobson, S. and Goddard, J. (2001). The Economics of Football, Cambridge University Press.

Duque. J.L. and Ferreira, N.A., (2005). "Explaining share price performance of football clubs listed on the Euronext Lisbon". ISEG - Universidade Tecnica de Lisboa Business Administration Working Paper No. 05-01.

Edmans, A., Garcia, D. and Norli, Ø. (2007). "Sports sentiment and stock returns", Journal of Finance, Vol. 62, pp.1967-1998.

Europol (2013). "Update - Results from the largest football investigation in Europe", available at: https://www.europol.europa.eu/content/results-largest-footballmatch-fixing-investigation-europe

Fama, F. (1965). "The behavior of stock-market prices", The Journal of Business, Vol.38 No.4, pp. 34-105.

Floros, C. (2014). "Football and stock returns: New evidence", in Procedia Economics and Finance, Vol. 14, pp. 201-209

Gils, F. (2016). "How do stocks of listed football clubs react to the sportily performance of these football clubs? A case study for European listed football clubs". Master Thesis, Tilburg University.

Glenn M.W. (2010). Essentials of Sports Law, 4th edition, ABC-CLIO, LLC.

Gökten, S. and Karatepe, S. (2015), "Effects of match-fixing related publications on football clubs' stock prices: An example from Turkey". Muhasebe ve Finansman Dergisi, Vol.68, pp.169-184.

Güngör, A. (2014). “An analysis of relationship between sporting success and financial performance in football industry, the case of Turkey", Istanbul Üniversitesi Sosyal Bilimler Dergisi, Vol.1, pp. 16-36. 
Hamil, S and Morrow, S. (2011). "Corporate social responsibility in the scottish premier league: context and motivation”, European Sport Management Quarterly, Vol.11, No.2, pp.143-170.

Harty, C. (2014). "5 Football Clubs Listed on the Stock Exchange", The Richest, 8 March, available at: http://www.therichest.com/sports/soccer-sports/5-footballclubs-listed-on-the-stock-exchange/

Kalb, C (2011). "Integrity in sport - understanding and preventing match-manipulation" available at: http://www.sportaccord.com/multimedia/docs/2012/04/SportAccord IntegrityReport_A4_V2UpdatedApril2012.pdf

Kaplanski, G. and Levy, H. (2010). "Exploitable predictable irrationality: The FIFA world cup effect on the US stock market", Journal of Financial and Quantitative Analysis, Vol. 45, No. 2, pp.535-553.

Mandelbrot, B. (1963). "The variation of certain speculative prices", Journal of Business, Vol. 36, pp. 394-419.

Match-fixing in sport (2012). A mapping of criminal law provisions in EU 27, KEA European Affairs, available at: http://www.keanet.eu/docs/study-sports-fraudfinal-version en.pdf

Milliyet, Arşiv, available at: http://www.milliyet.com.tr

Morrow, S. (1999). "The New Business of Football", Accountability and Finance in Football. Macmillan Press Ltd., pp. 93-97.

Nowy, T. and Breuer, C. (2016). "Match-fixing in European grassroots football", European Sport Management Quarterly, pp.1-21.

Özdurak, C. and Ulusoy, V. (2013). "Moneyball in the turkish football league: A stock behavior analysis of Galatasaray and Fenerbahce based on information salience". Journal of Applied Finance \& Banking, Vol. 3, No.4, pp.1-12.

Palomino, F., Renneboog, L. and Zhang, C. (2005). "Stock price reactions to short-lived public information: The case of betting odds", TILEC Discussion Paper, DP 2005-016, Tilburg University.

Palomino, F., Renneboog, L. and Zhang, C. (2009). Information Salience, Investor Sentiment and Stock Returns: The Case of British Soccer Betting. Journal of Corporate Finance, 15(3), 368-387.

Renneboog, L. and Vanbrabant, P. (2000). "Share Price Reactions to Sporty Performances of Soccer Clubs Listed on the London Stock Exchange and the AIM". Working Paper, Tilburg University.

Peurala, J. (2013). "Match-manipulation in football - the challenges faced in Finland", Int Sports Law, Vol. 13, pp. 268-286

Saraç, M. and Zeren, F. (2013). "The effect of soccer performance on stock return: Empirical evidence from "the big three clubs" of turkish soccer league", Journal of Applied Finance \& Banking, Vol. 3, No. 5, pp. 299-314.

Scholtens, B. and Peenstra, W. (2010). "Scoring on the stock exchange? The effect of football matches on stock market returns: An event study", Applied Economics, Vol.41, No. 25, pp. 3231-37. 
SMG Insight (2013). "Sports Turkey: Popularity of Sports in Turkey" available at: http://www.smg-insight.com/research-reports/sports-turkey-research-report/

Stadtmann, G. (2006). "Frequent news and pure signals: The case of a publicly traded football club", Scottish Journal of Political Economy, Vol. 53, No. 4, pp.485-504.

Tufan, E. and Hamarat, B. (2014). "Has Borsa Istanbul been conceded goals by Fenerbahçe and Trabzonspor?", Journal of Applied Finance \& Banking, Vol. 4, No.2, 47-57.

Wilson, R., Plumley, D. and Ramchandani, G. (2013). "The relationship between ownership structure and club performance in the English Premier League", Sport, Business and Management: An International Journal, Vol. 3, No. 1, pp. 19-36. 